\title{
New Market, New Regulation and New Prospect - The Chinese Perspective
}

\author{
Wu Dingfu \\ CIRC, No. 15 jin rong dajie, Xicheng District, Beijing, China 10032. \\ E-mail: guangyi_zhao@circ.gov.cn
}

China is a new insurance market attracting worldwide attention. Meeting the golden opportunities of development, it is growing fast with enormous potential though it remains in the primary stage of development. This new market brings up the new relationship between the development of the insurance sector and the overall social and economic situation. It is the overall objective to build a harmonious society in China, and the growth of insurance is an important guarantee. Development is the primary task for the insurance regulation in China. Risk prevention and risk mitigation are the core contents of insurance regulation. It is expected that in the near future, insurance will become not only an important force in the financial field in China but also an essential guarantee for the Chinese people. To drive forth the amalgamation of the international insurance sector and the global economic and social developments, the paper proposes four recommendations. The Geneva Papers (2006) 31, 17-24. doi:10.1057/palgrave.gpp.2510068

Keywords: China; harmonious society; development; risk prevention and mitigation; cooperation

\section{Introduction}

In recent years, China has been deepening its reform and opening further to the outside world, and with a stable political situation and a fast-growing economy, people's living standard has been improving progressively, and the national economy and the society have achieved an unprecedented development. Driven by the economic development, the insurance sector is greeting a spring for expansion and is playing a more and more important role. The good development momentum and the huge growth potential make China an emerging market recognized by the international insurance world. The insurance regulation in the emerging Chinese market and the prospect of market development have become the focus of attention of the international insurance world.

\section{The new insurance market in China}

In contrast to the traditional international insurance sector, the emerging Chinese insurance market, which was born out of the traditional mode of the planned economy, has its special development track. A relatively late start, a huge space for growth and the shouldering of an urgent task for development are its basic characteristics. The emerging insurance market in China and the overall situation of the social and economic developments supplement each other and have a mutually 
beneficial interaction - these are its marked attributes, different from those of the insurance sectors of other countries.

\section{The basic characteristics of the emerging insurance market in China}

It is developing rapidly

The rapid economic development in China has created spacious room for the expansion of the insurance sector. Since 1980, the insurance sector has been one of the fastest-developing trades in the national economy, with an average growth speed of over 30 per cent. By the end of 2004, the premium income reached USD 52.2 billion and the total insurance assets reached USD 143.3 billion. There are 69 insurance companies, five insurance groups and holding companies, four insurance asset management companies and 1317 professional insurance intermediaries in China. Altogether, 37 foreign insurance companies have been granted access to the Chinese insurance market. Among the list of top 500 firms in the world published by Fortune Magazine in 2003, 46 were insurance companies and 27 of them had set up business establishments in China.

\section{It is still in the primary stage of development}

By the end of 2004, the insurance penetration was 3.34 per cent and the insurance density was USD 40.5, each figure being lower than the world's average and those of many developing countries. There is a lack of creativity in insurance products; product structure is not perfect; management mechanisms need improvement; the level of information is not high; the quality and the effectiveness still need enhancing; and the governance structure of insurance companies is imperfect and risk control cannot be ignored.

\section{It is facing a golden opportunity for development}

The continuous and rapid growth of the Chinese economy has stimulated the demand for insurance; the reform of the social security system has provided a broad stage for commercial insurance and the strategic restructuring of the economy has created vast market space for commercial insurance. After the accession to the WTO, China stepped into the international market with a wider scope, a broader field and at a deeper level, and this has brought about new development space for the insurance sector. The GDP per capita has exceeded USD 1,000. Under such circumstances, there lies huge potential in the Chinese insurance market, and the insurance sector is becoming a flourishing sun-rising industry.

The new relationship between the development of the insurance sector and the overall social and economic situation

The development of the emerging Chinese insurance market is different from that of the traditional international insurance sector. The long-term development of the social and economic environments spontaneously made the traditional international insurance sector well established and vigorously developed. However, the Chinese 
insurance market developed in a synchronized pace with the development of the Chinese society and the economy, and it plays a more active role, being a key element for social and economic developments as well as sharing in the results of the economic growth. The Chinese insurance market and the overall social and economic situation have a new relationship, supplementing each other in a mutually beneficial interaction. While advancing sustainable, rapid and healthy economic growth, the Chinese insurance sector shoulders the important mission to perfect social security, adjust income distribution, resolve potential contradictions and maintain social stability.

To build a harmonious society is the overall objective of the social and economic developments in China

China is experiencing the transition from a planned economy to a market economy. The economy is growing rapidly, while the social administration remains relatively backwards, and there lie some notable elements restricting the all-round social and economic developments. Environmental pressure is increasing, and the investment and financial systems need improvement. The tasks regarding employment and social security are heavy; peasants' income generation is slow, and the income gap between some members of the society and others is too big. The development of social causes is slow, medical and health-care systems are still imperfect, and the issue of safe production cannot be neglected.

In the current situation, the overall objective of the social and economic developments is to try to build a harmonious society. Specifically, the objective is to build a society defined by democracy, the rule of law, equity, justice, sincerity, amity, vitality, stability, orderliness and the harmonious coexistence of man and nature. We should adhere to the scientific view of development, and balance urban and rural development, development among regions, economic and social development, the harmonious development of man and nature and domestic development; we should open more widely to the outside world, concentrating on resolving prominent contradictions in the economic and social developments and properly balancing reform, development and stability so as to promote the all-round, balanced and sustainable development of the economy and the society.

\section{Insurance is an important guarantee for building a harmonious society}

Building a harmonious society is a hard and complicated systematic project, and it is a very long historical process which advances progressively with the development of the economy, politics and culture. During this process, insurance exerts a special function and plays a non-substitutable essential role. The development of the modern insurance sector endows insurance with three main functions: economic compensation, financing and social administration. From the point of view of the development of the Chinese insurance sector, the functions of economic compensation and financing are brought into play little by little through compensating the insured in time and investing in currency and capital markets to support the economic development. More importantly, the insurance sector is exerting a more and more important function of social administration in four ways, including social security, social risk, social 
relationship and social credit, and it is of great significance to build a harmonious society.

By bringing the three main functions into play, insurance can optimize the functioning environment of the economy and promote its coordinated and sustainable development. It can perfect the social security system and serve the government's macro-regulation. It can improve the living standards of the people, promote their comprehensive development and speed up all-round social progress. In China, insurance oversteps the economic significance of common financial products, shouldering an essential social mission and obtaining an immense social field of vision. It can be said that the development of the Chinese insurance sector has not only the economic significance of broad market prospects and enormous commercial worth, but also the essential social and political significance of safeguarding social justice and serving the harmonious development of the society.

\section{The insurance regulation in the emerging market}

The characteristics of the new Chinese market determine the dialectical relationship among insurance regulation, the development of the sector and its risk prevention. Promoting development and preventing risk are the two missions of insurance regulation in China, while the healthy development of the insurance sector requires us to strengthen the regulation and prevent risks.

\section{Development is the primary task for the insurance regulation in China}

The full functioning of the three essential functions of insurance rests with the great progress made in the insurance sector. Without its development, the insurance sector cannot follow the steps of the developments of society and the economy, and thus cannot serve the people at large. Needless to say we have to perfect the regulation. We must unswervingly regard the development of insurance as the primary task of insurance regulation, promoting development through regulation and carrying out the regulation when providing a service, and make great efforts to expand and strengthen the Chinese insurance sector. Only if we persist in developing and improving the capability of insurance enterprises to withstand risks, can we prevent and resolve risks effectively and radically and maintain the stability of the insurance market system.

The practice of the development of the Chinese insurance sector in over 20 years demonstrates that the reform and opening-up are the only way to push on the construction of the insurance regulatory system in China. In order to cope with the system barrier of fettering development, the China Insurance Regulatory Committee has forged ahead with the reform of the insurance regulatory system to create a good system environment for the development of the insurance sector. On the one hand, it implemented and deepened the reform of insurance enterprises and explored effective operating methods of insurance. It advanced the transformation of state-owned insurance companies into stock companies, and successfully accomplished their reorganization and restructuring, and entered the overseas stock market. It perfected the operational mechanism of joint-equity insurance companies, optimized the 
ownership structure and regulated the governance structure. It improved the system of utilizing and managing insurance funds and established insurance asset management companies, carrying out professional management and centralized utilization of insurance funds. On the other hand, it seriously complied with the Administrative Licensing Law and actively drove forward the reform of the system of administrative licensing: cleaning up the licensing content not in line with regulations and reducing unnecessary administrative licensing proceedings. It issued the Measures of the Implementation of Administrative Licensing and perfected the examination and approval procedures. It strengthened law enforcement and monitoring and strengthened the consciousness on responsibilities.

Meanwhile, the China Insurance Regulatory Commission continuously brought forth strong measures, carrying out regulation when providing service and promoting development through regulation, so as to strive to establish a unified and open modern insurance market system with orderly competition. It perfected the access mechanisms of the insurance market and diversified the main bodies of the market. It energetically advanced creativity in insurance products and improved the level of service. It allowed the investment of insurance funds directly in financial instruments such as stocks, approved insurance funds in foreign exchange to be utilized overseas and expanded the channels of utilization of insurance funds. It allowed insurance companies to issue subordinated debts to add to the financing channels of insurance companies.

After China's accession to the WTO, the China Insurance Regulatory Commission has been strictly fulfilling the commitment for joining the WTO and pressing ahead steadily with opening wider to the outside world to strive to establish a modern insurance regulatory system under the opening-up conditions. It has been conscientiously putting into practice the guideline of "introducing" and "going global", approving qualified foreign insurance companies to come to China to start business and borrowing advanced concepts, experience, techniques and assets from the international insurance sector, so as to make great efforts to advance the common development of the Chinese insurance sector and the international insurance market.

\section{Risk prevention and risk mitigation are the core contents of insurance regulation}

Strengthening insurance regulation and preventing and resolving risks are always at the core of the work of the China Insurance Regulatory Commission. Following the guiding principle of "making a balanced plan, consolidating the foundation and strengthening the regulation", we created a modern insurance regulatory system, the core of which is market behaviour and solvency. The China Insurance Regulatory Commission is making great effort to construct the five lines of defense of risks in the insurance sector, with corporate governance as the basis, the regulation of solvency as the core, on-site inspections as an important means, the regulation of funds utilization as a key function and insurance guarantee funds as protection. Through the establishment and the perfecting of the internal risk management system, the reporting system on solvency, the financial analysis and check-up system, the regulatory intervention system and the follow-up remediation system of insurance companies, the China Insurance Regulatory Commission is achieving the transformation from a static 
regulation based on business scale to a dynamic regulation based on risks; from the regulation motivated by external factors to the regulation, with the risk management of insurance companies themselves acting as the intrinsic regulatory need, and from the ex post result-oriented regulation to the ex ante process-oriented regulation.

In the ongoing build-up of the insurance regulatory system, we will expect the insurance regulatory system framework, including solvency, corporate governance and market behaviour put forward by the IAIS, to go on perfecting the contents of the insurance regulatory system in China and advancing the common developments of the three backbones of the insurance regulation. We will further deepen the reform of insurance companies and perfect the corporate governance and the internal control construction of insurance companies. We will strengthen the solvency regulation and perfect the financial analysis system and the actuarial system. We will strengthen the market behaviour regulation and the scrutiny of legal compliance. We will put into practice the regulation on insurance guarantee funds and perfect its management mechanism. We will deepen the reform of the management mechanism of the insurance funds utilization, and enhance the management of the matching of assets and liabilities. We will strengthen the construction of the credibility system and the protection of the interests of the insured.

\section{The new prospect of the development of the Chinese insurance market}

The core mission of serving the harmonious society in an all-round way provides the Chinese insurance sector with a new bright prospect. The Chinese insurance sector will properly handle the relationship between current interests and long-term development, lay equal stress on the economic benefit and the social benefit, try to start a new phase of development for the insurance sector, and protect and support the society and the economy. Currently, the main issue of the Chinese insurance sector is that its development could not match the developments of the national economy and the society and people's living needs. Therefore, the direction of the development of the Chinese insurance sector at this stage is to be guided by the scientific view of development, adhere to putting the people first, put serving the people at large as the basic goal of development, and explore a path of development with Chinese characteristics. It is expected that in the near future insurance will become not only an important force in the financial field in China but also an essential guarantee for the Chinese people to live and work in peace and contentment.

In the next period, the Chinese insurance sector will focus on business in four areas: enterprise annuity, agriculture insurance, health insurance and liability insurance, striving to provide the old-age security system and the health security system for the Chinese people (who account for one-fifth of the world population), to provide support for venture investment for peasants (who account for over half of the population in China) and to resolve social issues and maintain social stability. In the process of building a well-off society in an all-round way and a socialist harmonious society, the insurance sector is playing an increasingly important positive role. 


\section{Four recommendations for the development of the international insurance sector}

With the advancement of economic globalization and financial liberalization, the time when the insurance sectors of various countries all over the world compete with each other in the common market and amalgamate with each other has arrived. Under such circumstances, in order to drive forward the amalgamation of the international insurance sector and the global economic and social developments, and improve the capability on risk management and sustainable development, we would like to make the following recommendations:

Laying stress on bringing the social function of insurance into play and focusing on the harmonious development of the society

Besides enlarging market scale, the international insurance industry should focus on the integration of commercial benefit with serving the society, and try to promote the harmonious development of the society as well as raise the quality of the lives of people, so as to lay a basis for the long-term development of the insurance sector and create a win-win situation among society, the people and the insurance firms.

\section{Promoting the coordinated development of the traditional market and the emerging market, and pushing the all-round progress of the international insurance sector}

The current situation of the international insurance sector developing in an imbalanced way seriously prevents insurance from playing a positive role in promoting world peace and development, and weakens the international significance of the insurance system. In the long term, this will make the international insurance lose the stamina in its development. Therefore, we should promote the coordinated development of the traditional markets and the emerging markets of the international insurance sector, support and make them complement each other and accelerate their development, so as to achieve an all-round progress of the international insurance sector.

Strengthening innovations in insurance, improving the capability of the insurance sector to withstand risks and widening the space for development of the insurance sector

In recent years, the contents of risk management have been changing; the trade liberalization of insurance services is expanding, mixed operations in the financial field are developing progressively, and information technology is being extensively applied to the insurance field. These new trends have brought forward new challenges to the international insurance sector, but at the same time they have created good opportunities. Faced with these new trends, the international insurance sector should look at them in an all-round manner and handle them dialectically. By strengthening innovations in insurance, resolving business risks and expanding space for development, the international insurance sector should better play the social and economic functions of insurance to serve human society. 
Strengthening the international exchanges of insurance and developing insurance cooperation at different levels and in various forms

Exchange and cooperation are the key means to promote development. The international insurance sector should make great efforts to push forward the exchange and cooperation at various levels and in various forms among the insuranceregulatory authorities of different countries, the insurance circles and the international insurance organizations, so as to promote the common progress of the development of insurance of each country and its level of regulation.

Nowadays, when peace and development become the mainstream of the world, we believe that the direction of the development of the Chinese insurance sector has a broad future. As the pivot of social and economic activities, the insurance sector is playing an indispensable role in promoting economic growth and maintaining social stability and it will surely make more positive contributions to world peace and development.

\section{About the Author}

Wu Dingfu is Chairman of the China Insurance Regulatory Commission (CIRC). 